\title{
CLINICAL FEATURES AND PREVALENCE OF GASTROESOPHAGEAL REFLUX DISEASE IN INFANTS ATTENDING A PEDIATRIC GASTROENTEROLOGY REFERENCE SERVICE
}

\author{
Yu Kar Ling KODA, Marcos J. OZAKI, Kelly MURASCA and Eliana VIDOLIN
}

\begin{abstract}
Context - In infants, it is not always easy to distinguish between pathological and physiological gastroesophageal reflux based only on clinical criteria. In Brazil, studies about gastroesophageal reflux disease in infants are few and are even rare those that used prolonged esophageal $\mathrm{pH}$ monitoring for its evaluation. Objective - To describe the clinical features of gastroesophageal reflux disease and to determine its prevalence in infants with gastroesophageal reflux attending a tertiary Pediatric Gastroenterology Service and submitted to esophageal $\mathrm{pH}$ monitoring for investigation. Methods - Descriptive study in 307 infants in whom esophageal pH monitoring (Mark III Digitrapper, Synectics Medical AB, Sweden) was performed during the period December, 1998-December, 2008. The clinical features studied were age group (1-12 months and 13-24 months), and clinical manifestations that motivated the indication of pH monitoring. Results - One hundred twenty-four (40.4\%) were female and $183(59.6 \%)$ male with mean age $12.2 \pm$ 6.2 months (1-23 months). The prevalence of gastroesophageal reflux disease was $18.2 \%(56 / 307)$. One hundred forty-eight (48.2\%) were 1-12 months old and 159 (51.8\%), 13-24 months. No significant difference was found between the prevalence of these two age groups $(P=0.3006)$. Gastroesophageal reflux disease was more frequent in those with digestive manifestations $(24.2 \%)$, crisis of cyanosis/apnea (23.8\%) and mixed manifestations (21.5\%). Respiratory manifestations were the most frequent indication ( $39.1 \%)$ of $\mathrm{pH}$ monitoring. However, the prevalence of gastroesophageal reflux disease was lower $(12.5 \%)$ in this group compared with in those with digestive manifestations $(P=0.0574)$, crisis of cyanosis/apnea $(P=0.0882)$ and mixed manifestations $(P=0.1377)$. All infants that presented clinical manifestations as crisis of cyanosis/apnea and abnormal $\mathrm{pH}$-metry were $\leq 3$ months of age. Conclusions - In our Service, the prevalence of gastroesophageal reflux disease associated with acid reflux in infants revealed elevated. Infants with crisis of cyanosis/apnea constitute risk population for gastroesophageal reflux disease in which diagnostic investigation needs to be considered.
\end{abstract}

HEADINGS - Gastroesophageal reflux. Esophageal pH monitoring. Infant.

\section{INTRODUCTION}

Gastroesophageal reflux (GER) should be understood as passive passage of gastric contents in the esophagus without any implication to its etiology ${ }^{(18,21)}$. It can be separated into two categories, normal physiological reflux and pathological reflux. In physiological GER, complications due to reflux are not present while in pathological GER, also known as gastroesophageal reflux disease (GERD), reflux is associated with signs and symptoms of complications involving digestive and/or respiratory and/or other systems.

There is a fundamental difference between physiological GER in adults and in children. In adults, GER is an eventual phenomenon that occurs in brief moments mainly during the day and after meals being, in most cases, totally asymptomatic. In children, especially in newborns and infants, GER is an almost habitual phenomenon and frequently symptomatic. Its most frequent manifestations are regurgitation and/or vomiting. In approximately $80 \%$ of the infants, regurgitation and/or vomiting appear in the first months of age, generally between 2 and 4 months, peaking at 4 to 5 months, tend to decrease in the second semester and to disappear in the second year of life ${ }^{(3,15,23)}$. In these cases, no complications due to GER were observed, the nutritional status and the humor are preserved and the infants are usually described as "happy spitters" $(15,17)$.

The main conditioning factors of physiological GER in newborns and infants are constituted by immaturity of anti-reflux mechanisms as well as by predominantly liquid meals and horizontal decumbent proper of this age group. As the maturity of antireflux mechanisms occurs and a predominantly solid meal and the erect position become to be adopted

From the Gastroenterology Unit, Instituto da Criança - Hospital das Clínicas da Faculdade de Medicina da Universidade de São Paulo, SP, Brasil.

Correspondence: Prof. Yu Kar Ling Koda - Av. Paulista, 2494 - sala 13 - Cerqueira César - 1310-300 - São Paulo, SP, Brasil. E-mail : yu.koda@icr.usp.br 
by the infant, the reflux not only decrease in frequency but also become less symptomatic thus acquiring gradually the pattern of physiologic GER observed in older children and in adults.

However, it is well known, nowadays, that GER, though can be a phenomenon without clinical consequences in most newborns and infants, can also be an important cause of morbidity in others when provokes complications in the digestive and/or respiratory and/or other systems assuming, thus, the characteristics of GERD. According to Aronow and Silverberg ${ }^{(1)}$, in the first year of age, $6 \%-7 \%$ of the infants look for medical attention due to GER symptoms and most of them receive some treatment, $1 \%-2 \%$ need complementary investigation and about $1 \%$, anti-reflux surgery.

Due to overlap of the symptoms and/or its non specificity, distinguishing between pathologic and physiologic gastroesophageal reflux in infants and children is not always easy. The availability of investigative techniques like intraluminal esophageal $\mathrm{pH}$ probe helped, in certain way, in this differentiation as well as in recognizing the importance of GERD as primary or secondary factor in some of its typical or atypical clinical presentations. After widely used in adults, this kind of investigative tool began to be used in children since 1974. In spite of the pertinent criticisms $^{(6,11)}$ and the emergence of new techniques like intraluminal esophageal impedance, prolonged esophageal $\mathrm{pH}$ monitoring is still considered, within the several exams now available for the study of GERD, a good investigative method for the detection and quantification of acid GER, especially in Brazil where more modern techniques are still limited in their availability.

The technique modality of esophageal $\mathrm{pH}$ monitoring most used currently is the one that uses a portable computerized device registering intraluminal esophageal $\mathrm{pH}$ that allows its use ambulatory. The advantage of this technique is the possibility of performing investigations under habitual conditions of life of the child and for a prolong period of time (18 or 24 hours or more).

In Brazil, studies about GERD in infants are few $(5,12,19)$ and are even rare those that used prolonged esophageal $\mathrm{pH}$ monitoring for its evaluation ${ }^{(12)}$.

The present study aimed to describe some clinical aspects of GERD associated to acid reflux and to determine its prevalence in a population of infants with GER attending a tertiary reference Service of Pediatric Gastroenterology in the city of São Paulo, SP, Brazil.

\section{METHODS}

Clinical and 24-hour-pH-metry data of infants referred for investigation of GERD between December 1998 and December 2008 were retrospectively reviewed. The data were collected from a standard protocol. $\mathrm{pH}$-metry tests with technique problems, inconsistency of diary recordings, $\mathrm{pH}$ monitoring less than 18 hours and exams performed for treatment controls were excluded. Infants using any oral or inhaled bronchodilator therapy, oral, nasal or inhaled corticosteroids or antibiotics at the time of the test were excluded. Patients using any of these drugs and/or $\mathrm{H}_{2}$ blockers/ prokinetic, antacid and xanthines interrupted the treatment at least 3 days before the $\mathrm{pH}$ monitoring and in the case of proton pump inhibitors, at least 7 days. Other exclusion criteria were history of neurological impairment, congenital gastrointestinal disease, or previous surgery of esophagus or stomach. A minimum 6-hour fasting period was required prior the test. A total of $307 \mathrm{pH}$-metry tests performed in 307 infants between 1-14 months of age fulfilled the criteria and were included in the study.

The infants were grouped, according to their age at the time of the exam into age group 1-12 months and 13-24 months. The clinical manifestations that motivated the indications for $\mathrm{pH}$-metry test were classified into: 1. Digestive manifestations represented predominantly by regurgitation/ vomiting; 2 . Respiratory manifestations that included chronic coughing, stridor, choking, wheezing and recurrent pneumonia/ bronchopneumonia; 3 . Crisis of cyanosis or apnea; 4 . Mixed manifestations characterized by different combinations of regurgitation/vomiting with chronic coughing, stridor, choking, wheezing, recurrent pneumonia/bronchopneumonia or crisis of cyanosis or apnea, and 5. Other manifestations represented by poor weight gain, abnormal movements/ postures, excessive/persistent crying/irritability, feeding and sleeping disturbances and cystic fibrosis.

Intraesophageal $\mathrm{pH}$ monitoring was performed with a MKIII Digitrapper (Synectics Medical AB, Sweden) connected to an antimony electrode (diameter of $2.1 \mathrm{~mm}$ pediatric crystal antimony multi-use $\mathrm{pH}$ Catheter, Medtronic). The electrode was calibrated before and after each investigation at $\mathrm{pH} 7.01$ and $\mathrm{pH} 1.07$ buffer solutions (Synectics Medical). The probe was inserted through one of the nostril and the location of the electrode was assessed according to the formula described by Strobel et al. ${ }^{(26)}$ and confirmed by fluoroscopy at the third vertebra above the diaphragm ${ }^{(29)}$. Data were analyzed with the EsopHagram software from Gastrosoft (version 5.7).

Due to the social-economic and cultural background of the patients attending the institution, the test was not performed in ambulatory system but as in-patient with the infant interned during 24 hours together with the mother or a responsible person ${ }^{(10)}$. The infants received their habitual alimentation and carried out their activities without restriction. During the $\mathrm{pH}$ monitoring period, the accompanying person was asked to complete a diary which included the periods of food intake, awakening and asleep, and supine or erect posture as well as the occurrence of symptoms like regurgitation/vomiting, coughing, wheezing, apnea and cyanosis ${ }^{(10)}$.

The four classical parameters were analyzed: reflux index (RI), no. of episodes/24 hours, duration of the longest episode (minutes) and no. of episodes with duration $>5$ minutes $^{(29)}$. GER in pH-metry was defined as a fall of intraesophageal $\mathrm{pH}$ below 4 with a duration $\geq 15$ seconds $^{(29)}$. $\mathrm{pH}$-metry was considered positive for GERD when RI was $>10 \%$ for infants of 01-12 months of age and $>6 \%$ for those of 13-24 months ${ }^{(27,28)}$. 


\section{Ethical considerations}

The study protocol was approved by the Research Ethics Committee of the institution. As it is a descriptive and retrospective study of data collected from medical records, written informed consent from the subjects was dispensed.

\section{Statistical analysis}

Qualitative variables were described by their frequencies. Fisher's test was used to study the association between these frequencies and the positive $\mathrm{pH}$-metry tests. Levels of $P \leq$ 0.05 were considered statistically significant.

\section{RESULTS}

One hundred twenty-four infants $(40.4 \%)$ were female and $183(59.6 \%)$ male. Mean age at the time of the $\mathrm{pH}$-metry test was $12.2 \pm 6.2$ months (1-23 months). One hundred forty-eight (48.2\%) were in the age group 1-12 months and $159(51.8 \%)$ in $13-24$ months.

$\mathrm{pH}$-monitoring was most frequently indicated in infants with respiratory manifestations (39.1\%), followed by those with mixed manifestations $(21.2 \%)$, digestive manifestations $(20.2 \%)$, crisis of cyanosis/apnea $(13,7 \%)$ and other manifestations $(5.8 \%)($ Table 1$)$.

TABLE 1. Age, sex, and clinical manifestations that motivated the indication for prolonged $\mathrm{pH}$ monitoring in 307 infants

\begin{tabular}{lc}
\hline Age $($ mean $\pm \mathrm{SD})$ & $\begin{array}{c}12.2 \pm 6.2 \mathrm{mo}(1-23 \mathrm{mo}) \\
\mathrm{n}(\%)\end{array}$ \\
Age group 1-12 mo & $148(48.2)$ \\
Age group 13-24 mo & $159(51.8)$ \\
Sex & $\mathbf{n}(\%)$ \\
$\quad$ Female & $124(40.4)$ \\
$\quad$ Male & $183(59.6)$ \\
Clinical manifestations that motivated & $\mathbf{n}(\%)$ \\
the indication for $\mathrm{pH}$ monitoring & \\
Digestive & $62(20.2)$ \\
Respiratory & $120(39.1)$ \\
Crisis of cyanosis/apnea & $42(13.7)$ \\
Mixed & $65(21.2)$ \\
Other & $18(5.8)$ \\
\hline
\end{tabular}

pH-metry positive for GERD was found in $56(18.2 \%)$ infants. Mean values for four classical parameters analyzed were: $\mathrm{RI}=13.1 \pm 6.8(6.5-42)$; no. of episodes $/ 24$ hours $=58.4$ \pm 24.5 (17-158); duration of the longest episode (minutes) $=35.2 \pm 28.6$ (6-13) and no. of episodes with duration $>5$ minutes $=6.7 \pm 4.1(1-19)($ Table 2$)$.

TABLE 2. Mean and standard deviation of the four classical parameters of prolonged esophageal monitoring in 307 infants

\begin{tabular}{lcc}
\hline Parameters & $\begin{array}{c}\text { Normal } \mathrm{pH} \text {-metry } \\
\mathbf{n}=251(81.8 \%)\end{array}$ & $\begin{array}{c}\text { Abnormal } \mathrm{pHmetry} \\
\mathbf{n}=56(18.2 \%)\end{array}$ \\
\hline RI $(\%)$ & $3.0 \pm 2.3(0-9.9)$ & $13.1 \pm 6.8(5.5-42)$ \\
no. episodes/24 hours & $30.4 \pm 21.6(1-121)$ & $58.4 \pm 24.5(17-158)$ \\
Duration of the longest episode (minutes) & $7.8 \pm 7.7(0-49)$ & $35.2 \pm 28.6(6-136)$ \\
no. episodes with duration $>5$ minutes & $1.2 \pm 1.7(0-9)$ & $6.7 \pm 4.1(1-19)$ \\
\hline RI = reflux index & &
\end{tabular}

As to the age group, $\mathrm{pH}$-metry positive for GERD was detected in $23(15.5 \%)$ of the infants with age between $1-12$ months and in $33(20.7 \%)$ between $13-24$ months. There was no significant difference between the prevalences found in these two age groups $(P=0.3006)$ (Table 3$)$.

TABLE 3. Results of prolonged esophageal $\mathrm{pH}$ monitoring in 307 infants according to age group

\begin{tabular}{lccc}
\hline $\begin{array}{l}\text { Age group } \\
\text { (months) }\end{array}$ & $\begin{array}{c}\text { Normal pHmetry } \\
\mathbf{n}(\%)\end{array}$ & $\begin{array}{c}\text { Abnormal pHmetry } \\
\mathbf{n}(\%)\end{array}$ & $\begin{array}{c}\text { Total } \\
\mathbf{n}(\%)\end{array}$ \\
\hline $01-12$ & $125(84.5)$ & $23(15.5)$ & $148(48.2)$ \\
$13-24$ & $126(79.3)$ & $33(20.7)$ & $159(51.8)$ \\
Total & $251(81.8)$ & $56(18.2)$ & $307(100)$ \\
\hline
\end{tabular}

Fisher's test $P=0.3006$

$\mathrm{pH}$-metry positive for GERD was more frequently observed in infants with digestive manifestations $(24.2 \%)$, crisis of cyanosis/apnea (23.8\%) and mixed manifestations $(21.5 \%)$ and less in those with respiratory manifestations $(12.5 \%)$ as well as in those with other manifestations (11.1\%). However, statistical significant differences were not found (Table 4). All infants that presented clinical manifestations as crisis of cyanosis/apnea and abnormal $\mathrm{pH}$-metry were $\leq 3$ months of age (Table 4).

TABLE 4. Results of prolonged esophageal pH monitoring in 307 infants according to clinical manifestations that motivated the indication for the test

\begin{tabular}{lccc}
\hline Clinical manifestations & $\begin{array}{c}\text { Normal pHmetry } \\
\mathbf{n}(\%)\end{array}$ & $\begin{array}{c}\text { Abnormal pHmetry } \\
\mathbf{n}(\%)\end{array}$ & $\begin{array}{c}\text { Total } \\
\mathbf{n}(\%)\end{array}$ \\
\hline Digestive & $47(75.8)$ & $15(24.2)$ & $62(20.2)$ \\
Respiratory & $105(87.5)$ & $15(12.5)$ & $120(39.1)$ \\
Crisis of cyanosis/apnea & $32(76.2)$ & $10(23.8)$ & $42(13.7)$ \\
Mixed & $51(78.5)$ & $14(21.5)$ & $65(21.2)$ \\
Others & $16(88.9)$ & $2(11.1)$ & $18(5.8)$ \\
Total & $251(81.8)$ & $56(18.2)$ & $307(100)$ \\
\hline Fisher's test respiratory x digestive $(P=0.0574)$; respiratory x crisis of cyanosis/apnea $(P=0.0882)$; respiratory x mixed $(P=0.1377)$
\end{tabular}

\section{DISCUSSION}

Carre $^{(3)}$, in his classic retrospective study about GER associated with hiatal hernia in children, reported that almost all children presented symptoms before 3 months of age. On its natural course and in the absence of any therapy, GER resolved in only $60 \%$ to $65 \%$ of the children about the age of 18 months. In approximately $30 \%$, symptoms persisted until 4 years of age, $5 \%$ developed complications such as esophagitis and esophagus stenosis and 5\% died usually by pneumonia and malnutrition. However, because this was a select group of patients with an anatomic abnormality, it is unlikely that these results are generalizable to most symptomatic infants seen by pediatricians.

Shepherd et al. ${ }^{(25)}$ observed that $81 \%$ of the children with GER they followed, became symptomless at 18 months of age, $17 \%$ went to surgery and $2 \%$ persisted with symptoms beyond 2 years of age.

The natural history of GER in untreated infants (time when effective therapy was not available) described in these initial studies ${ }^{(3,25)}$ demonstrates that GER can reach 
spontaneous resolution in the majority of the cases. However, in approximately $20 \%$ to $35 \%$ of the cases, complications may appear constituting GERD. According to Boyle ${ }^{(2)}$, physiologic reflux may eventually become pathologic in any moment of it evolution and the factors determining the progression of a physiologic phenomenon to a pathologic condition are unknown.

The frequent regurgitation of the infants causes anxiety in parents that, most often, demand solutions from the pediatricians to relieve the situation. Over estimation of the symptoms, especially when restricted to the presence of regurgitation/vomiting, may lead to over diagnosis and over treatments of healthy infants that regurgitate. By the other way, under diagnosis of a pathological situation may put the infant in risk for the occurrence of severe complications. The pediatricians constantly face this dilemma, and the distinction between physiologic and pathologic GER is fundamental for an adequate approach of such cases.

Distinguishing between pathological and physiological gastroesophageal reflux in infants and children is not always straightforward and easy because the symptoms (regurgitation/ vomiting) may overlap or may be very nonspecific (excessive/ persistent crying/irritability, poor weight gain, feeding and sleeping disturbances, chronic respiratory disease).

Some authors have used clinical criteria to identify infants with probable GERD that needs complementary investigations ${ }^{(4,}$ 17). In Brazil, Costa et al. ${ }^{(4)}$, by applying a criteria based on Rome II criteria ${ }^{(20)}$ in a group of spitters infants attending a Public Health Service, found a prevalence of $11.1 \%$ of probable GERD. This prevalence is very similar to those described in foreign literature when the clinical criteria is adopted ${ }^{(13,15,17,30)}$.

In spite of pertinent criticism to the important variation of its sensibility ${ }^{(6,11)}$ and of introduction of new methods like esophageal impedance monitoring, prolonged esophageal $\mathrm{pH}$ monitoring, when adequately indicated and well performed, is still considered, among several tests available for the investigation of GER, a good method which allows the differentiation of physiologic and pathologic GER.

In our study, the prevalence of pathologic GER in infants, determined by 24 -hour $\mathrm{pH}$ monitoring, revealed to be elevated $(18.3 \%)$. The elevated prevalence may be explained by the characteristics of the population studied. Our institution is a tertiary level pediatric teaching hospital to where children with the most severe diseases are referred from different pediatric specialties.

When compared, our findings were very similar to those of the literature. Heine et al. ${ }^{(8)}$ in a retrospective study of 125 infants attending a tertiary level pediatric teaching hospital, with median age 4.2 months (0.6-9.3 months), persistent distress (parent-reported excessive crying and fussing for at least 3 hours per day for a minimum of 3 consecutive weeks) and symptoms suggestive of GER or esophagitis who had upper gastrointestinal endoscopy and esophageal 24-hour $\mathrm{pH}$ monitoring, detected GERD in $32(25.6 \%)$. In a large hospital of Brussel, Salvatore et al. ${ }^{(23)}$ in 100 infants suspected of having GERD (regurgitation or vomiting with or without distress) and underwent prolonged esophageal $\mathrm{pH}$ monitoring, found abnormal pH study in $21(21 \%)$.
Neufeld et al. ${ }^{(16)}$ performed esophageal $\mathrm{pH}$ monitoring in 76 children with symptoms of GER (digestive and respiratory manifestations) attending a tertiary level hospital found a prevalence of $38.2 \%$ of GERD. This prevalence, superior to ours, could probably due to the difference of age groups of the children studied. Mean age of the children in our study was $12.2 \pm 6.2$ months while that of Neufeld et al. ${ }^{(16)}$ was 43 months 16 days \pm 48 months 17 days. It is well known that the prevalence of GERD varies according to the age group being lower in infants characterizing the predominance and the benign course of physiologic reflux, in contrast to what occurs in older children when the symptoms persist, because in these cases the prevalence of pathologic reflux usually increases.

Respiratory abnormalities have been frequently associated with $\operatorname{GER}^{(9,22,24)}$ so that nowadays these problems motivate early indication of esophageal $\mathrm{pH}$-metry, frequently as the first exam to be performed in the investigation of GER as the etiology of those diseases. In our study, respiratory manifestations motivated the indication for $\mathrm{pH}$ monitoring more frequently $(39.1 \%)$ than mixed $(21.2 \%)$ or digestive manifestations $(20.2 \%)$. This finding demonstrates acknowledgment and/or preoccupation of the pediatricians in relation to respiratory manifestations as symptoms of GER. It is interesting to point out that in our study, though not statistically significant, GERD was less frequently observed in the group with respiratory manifestations $(12.5 \%)$ than the group with digestive $(24.2 \%)$, crisis of cyanosis/apnea or mixed manifestations $(21.5 \%)$ as the main indication for esophageal pH-metry.

The finding of clinical manifestation as crisis of cyanosis/ apnea occurred exclusively in infants $\leq 3$ months of age in this study deserves attention. The percentage of indication for $\mathbf{p H}$ monitoring by this clinical manifestation $(13.7 \%)$ was comparatively lower than the percentages by digestive, respiratory or mixed manifestations. However, the percentage of abnormal pH-metry test, though not statistically significant, was superior to the group of respiratory manifestations.

Goldani et al. ${ }^{(7)}$ evaluated the indications and the results of esophageal $\mathrm{pH}$-metry in a demand population of a Pediatric Gastroenterology Service. They found that, in a total of 190 children and adolescents with ages between 0 to 14 years submitted to prolonged esophageal monitoring, $100(52.6 \%)$ were $0-24$ months of age and crisis of apnea and/or cyanosis constituted $20 \%$ of the indications of esophageal pH-metry that occurred predominantly in newborns and infants under 3 months of age $(55.3 \%)$. In these children, the percentage of positive exams $(76.3 \%)$ was much higher than ours. This difference may be explained that, in our studied population, newborns were not included.

In fact, description of crisis of cyanosis/apnea in newborns as symptoms of GER is frequent ${ }^{(14)}$. In a study of premature patients with nonspecific symptoms, investigated for GER by prolonged esophageal $\mathrm{pH}$ monitoring, Mezzacappa and Collares $^{(14)}$ diagnosed GERD in $56.4 \%$ of the premature newborns and $50 \%$ of those with crisis of cyanosis/apnea had abnormal pH-metry.

In view of these results, we, therefore, recommend that infants with crisis of cyanosis/apnea, especially those under 
3 months of age, must be remembered as a risk population for GERD in which diagnostic investigation should be considered.

\section{CONCLUSIONS}

In our service, the prevalence of GERD associated with acid reflux in infants detected by prolonged esophageal monitoring was elevated. Infants with crisis of cyanosis/apnea constitute risk population in which diagnostic investigation should be considered.

\section{ACKNOWLEDGMENT}

Special thanks to Dr. Ulisses Doria for their assistance in statistical analysis.

Koda YKL, Ozaki MJ, Murasca K, Vidolin E. Doença do refluxo gastroesofágico associada ao refluxo ácido em lactentes atendidos em um serviço de referência de gastroenterologia pediátrica. Arq Gastroenterol. 2010;47(1):66-71.

RESUMO - Contexto - Em lactentes, nem sempre é fácil diferenciar o refluxo gastroesofágico fisiológico do patológico baseado somente em dados clínicos. No nosso meio, são escassos os estudos sobre doença do refluxo gastroesofágico em lactentes, sendo ainda mais raros os que tenham utilizado a pHmetria esofágica prolongada para a sua avaliação. Objetivo - Descrever os aspectos clínicos da doença do refluxo gastroesofágico e determinar a sua prevalência em uma população de lactentes com refluxo gastroesofágico atendida e submetida a pHmetria esofágica num serviço terciário de gastroenterologia pediátrica. Métodos - Estudo descritivo em 307 lactentes submetidos a pHmetria esofágica (Digitrapper MKIII, Synectics Medical AB, Sweden) no período de dezembro de 1998 a dezembro de 2008. Os aspectos clínicos analisados foram: faixa etária (1-12 m e 13-24 m) e manifestações clínicas que motivaram a indicação de pHmetria. Resultados - Cento e vinte e quatro (40,4\%) eram meninas e 183 (59,6\%) meninos, com idade média de 12,2 \pm 6,2 m (1-23 m). A prevalência de doença do refluxo gastroesofágico foi de 18,2\% (56/307). Cento e quarenta e oito (48,2\%) tinham idades entre 1-12 m e 159 (51,8\%), 13-24 m. Não houve diferença significativa entre as prevalências observadas nessas duas faixas etárias $(P=0,3006)$. Doença do refluxo gastroesofágico foi mais frequentemente detectada nos lactentes com manifestações digestivas $(24,2 \%)$, crises de cianose/apneia ( $23,8 \%)$ e manifestações mistas (21,5\%). Manifestações respiratórias motivaram maior percentagem $(39,1 \%)$ de indicação de pHmetria. Entretanto, a prevalência de doença do refluxo gastroesofágico nesse grupo (12,5\%) resultou menor quando comparada com a de manifestações digestivas $(P=0,0574)$, crises de cianose/apneia $(P=0,0882)$ e mistas $(P=0,1377)$. Todos lactentes que apresentaram manifestações clínicas sob forma de crises de cianose/apneia e pHmetria alterada tinham idades $\leq 3$ meses. Conclusões - No serviço onde este estudo foi desenvolvido, a prevalência de doença do refluxo gastroesofágico associada ao refluxo ácido em lactentes, detectada através de pHmetria esofágica prolongada, revelou-se elevada. Lactentes com crises de cianose/apneia constituem população de risco para doença do refluxo gastroesofágico na qual investigação diagnóstica necessita ser considerada.

DESCRITORES - Refluxo gastroesofágico. Monitoramento do pH esofágico. Lactente.

\section{REFERENCES}

1. Aronow E, Silverberg M. Normal and abnormal GI motility. In: Silverberg M, editor. Pediatric gastroenterology. New York: Medical Examination Publ.; 1983. p.214-8.

2. Boyle JT. Gastroesophageal reflux in the pediatric patient. Gastroenterol Clin North Am. 1989;18:315-37.

3. Carré IJ. The natural history of the partial thoracic stomach (hiatus hernia) in children. Arch Dis Child. 1959;34:344-53

4. Costa AJF, Silva GAP, Gouveia PAC, Pereira-Filho EM. Prevalência de RGE patológico em lactentes regurgitadores. J Pediatr (Rio J). 2004;80:291-5.

5. Domingues CHD, Lago PM, Piva JP, Cantalice-Neto AF. Refluxo gastroesofágico em lactentes hospitalizados: estudo comparativo entre dois grupos. J Pediatr (Rio J). 1985;59:452-4

6. Fennerty MB, Castell D, Fendrick AM, Halpern M, Johnson D, Kahrilas PJ, Leiberman D, Richter JE, Sampliner RE. The diagnosis and treatment of gastroesophageal reflux disease in a managed care environment. Suggested disease management guidelines. Arch Intern Med. 1996;156:477-84

7. Goldani HAS, Silveira TR, Rocha R, Celia L, Dalle Molle L, Barros SGS Predomínio de manifestações respiratórias na indicação de pHmetria esofágica prolongada em crianças. Arq.Gastroenterol. 2005;42:173-7.

8. Heine RG, Cameron DJS, Chow CW, HiII DJ, Catto-Smith AG. Esophagitis in distressed infants: poor diagnostic agreement between esophageal $\mathrm{pH}$ monitoring and histopathologic findings. J Pediatr. 2002;140:3-4.

9. Kauer WK, Stein HJ, Mobius C, Siewert JR. Assessment of respiratory symptoms with dual $\mathrm{Ph}$ monitoring in patients with gastro-esophageal reflux disease. $\mathrm{Br} \mathrm{J}$ Surg. 2004;91:867-71.

10. Koda YKL. pHmetria esofágica prolongada. Utilização em pediatria. In: Nasi A, Michelsohn NH, editores. Avaliação funcional do esôfago. Manometria e pH-metria esofágicas. São Paulo: Roca; 2001. p.295-305.
11. Kroes RM, Mattijs EN, Jones RH. Gastro-oesophageal reflux disease in primary care. Comparison and evaluation of existing national guidelines and development of uniform European guidelines. Eur J Gen Pract. 1999;5:88-97.

12. Meyer R, Fischer GB. Associação entre refluxo gastroesofágico e quedas da saturação transcutânea de oxigênio da hemoglobina em lactentes com doença ventilatória obstrutiva crônica. J Pediatr (Rio J). 2001;77:89-95.

13. Miyazawa R, Tomomasa T, Kaneko H, Tachibana A, Ogawa T, Morikawa A Prevalence of gastro-esophageal reflux-related symptoms in Japanese infants. Pediatr Inter. 2002;44:513-6.

14. Mezzacappa MAMS, Collares EF. Utilização da monitorização prolongada do pH esofágico no diagnóstico da doença pelo refluxo gastroesofágico em recém nascidos. J Pediatr (Rio J). 1999;75:237-43.

15. Nelson SP, Chen EH, Syniar GM, Christoffel KK. Prevalence of symptoms of gastroesophageal reflux during infancy. A pediatric practice-based survey. Pediatric Practice Research Group. Arch Pediatr Adolesc Med. 1997;151:569-72.

16. Neufeld CB, Toporovski MS, Magni AM, Martins VJ, Toledo C. Contribuição ao estudo do refluxo gastroesofágico em crianças: correlação entre cortejo de sinais e sintomas clínicos e a prova de pHmetria esofágica de 24 horas. Rev Paul Pediatr. 2003;21:143-52.

17. Orenstein SR, Cohh JF, Shalaby TM, Kartan R. Reliability and validity of an infant gastroesophageal reflux questionnaire. Clin Pediatr (Phila). 1993;32:472-84.

18. Orenstein SR, Izadnia F, Khan S. Gastroesophageal reflux disease in children. Gastroenterol Clin North Am. 1999;28:947-69.

19. Quintella TMM. Avaliação do refluxo gastroesofágico na morbidade de lactentes chiadores atópicos e não-atópicos [dissertação]. Campinas, SP: Universidade Estadual de Campinas - UNICAMP; 1997.

20. Rasquin-Weber A, Hyman PE, Cucchiara S, Fleisher DR, Hyams JS, Milla PJ, Staiano A. Childhood functional gastrointestinal disorders. Gut. 1999;45(suppl 2):II60-8.

21. Rudolph CD, Mazur LJ, Liptak GS, Baker RD, Boyle JT, Colletti RB, Gerson WT, Werlin SL. Guidelines for evaluation and treatment of gastroesophageal 
reflux in infants and children: recommendations of the North American Society for Pediatric Gastroenterology and Nutrition. J Pediatr Gastroenterol Nutr. 2001;32:s1-s31.

22. Saint-Maurice D, Michaud L, Guimber D, Thumerelle C, Deschildre A, Turck $\mathrm{D}$, Gottrand F. Esophageal $\mathrm{pH}$-metry in children with recurrent respiratory events: diagnosis value of a day time esophageal $\mathrm{pH}$ monitoring. Arch Pediatr. 2002;9:1236-40.

23. Salvatore S, Hauser B, Vandemaele K, Novario R, Vandenplas Y. Gastroesophageal Reflux disease in infants: how much is predictable with questionnaires, $\mathrm{pH}$ metry, endoscopy and histology? J Pediatr Gastroenterol Nutr. 2005;40: $210-5$.

24. Sheikh S, Stephen T, Howell L, Eid N. Gastroesophageal reflux in infants with wheezing. Pediatr Pulmonol. 1999;28:181-6.

25. Shepherd RW, Wren J, Evans S, Sander M, Oug Th. Gastroesophageal reflux in children. Clinical profile, course and outcome with active therapy in 126 cases. Clin Pediatr (Phila). 1987;26:55-60.
26. Strobel CT, Byrne WJ, Ament ME, Euler AR. Correlation of esophageal lengths in children with height: application to the Tuttle test without prior esophageal manometry. J Pediatr. 1979;94:81-4.

27. Vandenplas Y, Sacre L, Loeb H. pH monitoring in children. Neth J Med 1989;34(suppl 1):s62-s73

28. Vandenplas Y, Goyvaerts H, Helven R, Sacre L. Gastro-esophageal reflux, as measured by 24 -hour $\mathrm{pH}$ monitoring, in 509 healthy infants screened for SIDSrisk. Pediatrics. 1991;88:834-40.

29. Vandenplas Y. Oesophageal $\mathrm{pH}$ monitoring: hardware and software. In: Vandenplas $\mathrm{Y}$, editor. Oesophageal $\mathrm{pH}$ monitoring for gastro-oesophageal reflux in infants and children. Chichester: John Wiley; 1992. p.84-5.

30. Wienbeck M, Barnert J. Epidemiology of reflux disease and reflux esophagitis Scand J Gastroenterol. 1989;156:7-13.

Received 6/5/2009. Accepted 8/7/2009. 